\title{
Time Overrun in Construction Projects from the Perspective of Project Management Consultant (PMC)
}

\author{
Aftab Hameed Memon ${ }^{1}$, Ismail abdul Rahman ${ }^{1 *}$, Mohd Razaki abdullah ${ }^{1}$, Ade Asmi Abdul Aziz ${ }^{1}$, \\ ${ }^{1}$ Universiti Tun Hussein Onn Malaysia, 86400 Parit Raja, Batu Pahat, Johor, Malaysia \\ *ismailar@uthm.edu.my
}

\begin{abstract}
Time Overrun is one of the most significant issues being faced by the construction industry today. There are various factors responsible for the time overrun which require serious attention to understand and address in order to achieve successful completion of projects on time. This is because time overrun has great impact to construction cost which can never be recovered. Thirty (30) large construction projects in Malaysia were identified facing Time Overrun during construction. Out of 30 projects, 17 (56.67\%) projects were caused by 1 100 days time overrun, 5 (16.67\%) projects in between 101 to 200 days, 5 (16.67\%) projects 201 to 300 days whereas $3(10 \%)$ projects were delayed for time period above 300 days. A structured questionnaire was conducted amongst personnel of project management consultants (PMC). The data was analyzed statistically to calculate the causes mean rank of time overrun. It also computed the level of agreement with Kendall's formula. Dominating factors affecting time overrun are cash flow \& financial difficulties faced by contractors, contractor's poor site management, and inadequate contractor experience, shortage of site works and ineffective planning \& scheduling. The results of this study will enhance the selection process of awarding construction job to the contractor.
\end{abstract}

Keywords: Time Overrun, Causes of Time overrun, PMC, Malaysian Construction Industri

\section{Introduction}

In construction industry one of the basic goals of practitioners is to achieve timely completion of projects within stipulated budget and required quality as each day of time overrun in the completion of any project has direct impact on the cost of project. In order to manage and control construction projects, there are various procurements strategies being adopted. Most popular strategies include traditional, management, integrated services and in-house teams (Ofori 1990). These strategies contain various methods of managing projects (Table 1).

In Malaysian, traditional lump sum system, design and build/turnkey system and Construction Project Management/Contract Management are commonly adopted in procurement strategies (CIMP 2007 and Rashid 2002). However, literature shows that in spite of adopting various management practices, construction projects in many countries are still facing problem of time overrun which needs very serious attention. Malaysian construction industry is also facing the same problem of time overrun. To avoid this issue, very first and most important step is to identify and understand the causes and factors responsible for that. Hence, this study was carried out to identify the major cause of time overrun in Malaysian construction industry. However, this study was focusing on management procurement projects only and the respondents were personnel from Project management consultants. 
Table 1 : Types of procurement methods \& its variations

\begin{tabular}{|l|l|}
\hline $\begin{array}{l}\text { Procurement } \\
\text { Strategy }\end{array}$ & Methods / Techniques \\
\hline Traditional & $\begin{array}{l}\text { Traditional Lump Sum System / Traditional System / } \\
\text { Design- Bid- Build / Open Tender Contracts } \\
\text { Negotiated Contracts } \\
\text { Best Value Procurement } \\
\text { Incentives Contracts }\end{array}$ \\
\hline Management & $\begin{array}{l}\text { Construction Project Management / Contract } \\
\text { Management } \\
\text { Construction Management at Risk / Management } \\
\text { Contracting }\end{array}$ \\
\hline Integrated & $\begin{array}{l}\text { Design and Build } \\
\text { Turnkey System }\end{array}$ \\
\hline In-house & $\begin{array}{l}\text { Self-Performance } \\
\text { In-House Teams } \\
\text { Job-Order Contract } \\
\text { Separate Contracts }\end{array}$ \\
\hline
\end{tabular}

\section{Related Works}

Construction industry is one of the most complex, fragmented industries referred as schedule and resource driven. In construction industry timely completion of project is a major criterion of project success (Rwelamilla and Hall1995). Time overrun is any delay beyond the baseline construction schedule. Minimizing time and cost is the main goal in managing a construction project. However, time delay frequently occurs in all phases of a construction project and consequently increases project total duration (Yang and Ou 2008). Very rarely projects are completed on time (Assaf and Al-Hejji 2006). This leads to pay serious attention to control construction time as each day of delay contributes a significant amount of revenue which is hardly recovered. Hence, a number of studies have been conducted to identify the factors causing time overrun. In Indonesia (Kaming et al. 1997) studied influencing factors on 31 high-rise projects and found out that the most important factors causing time overrun are design changes, poor labor productivity, inadequate planning, and resource shortages. Through a comparative study of causes of time overruns in construction projects in Hong Kong (Chan and Kumaraswamy 1997) found 5 principal causes of delays including Poor site management, Unforeseen ground condition, Low speed of decision making, Client-initiated variation and Necessary variations of works.

In Ghana, (Frimpong et.al. 2003) studied groundwater project and illustrated that owners, contractors and consultants ranked poor contractor management, monthly payment difficulties from agencies, material procurement, poor technical performances and escalation of material prices as major factors that can cause time overrun. Similarly (Mansfield et al. 1994) showed that the most significant factors affecting construction 
schedules were financing and payment for completed works, poor contract management, changes in site conditions, shortage of materials, and improper planning.

According to (Assaf and Al-Hejji 2006) 70\% of projects experienced time overrun. The average time delay ranges from $10 \%$ to $30 \%$ of the original duration of the project. The study identified 6 main causes including change order, delay in progress payment, ineffective planning and scheduling of project by contractor, poor site management and supervision by contractor, Shortage of labours and Difficulties in financing project by contractor as most critical factors responsible for this time overrun. Delayed payment was found to be the number one cause of schedule delays in the Zambian road construction industry followed by protracted financial processes in client organizations, financial difficulties that accompany the delayed release of funds by client organizations, contract modification, material procurement and changes in drawings, staffing problems, equipment unavailability, poor supervision, construction mistakes, poor coordination on site and changes in specifications (kaliba et. al. 2009). Unforeseen site conditions was found most prominent cause of schedule delay affecting total project duration and cost of project (Yang and Ou 2008)

\section{Identification of Projects Facing Time Overrun}

A number of projects facing the problem of time overrun were identified for the study. The attributes of the construction projects are presented in Table 2. The projects are mainly regarding the construction work awarded by MARA (government agency) which is distributed around Malaysia. From Table 2, it is observed that the minimum time over run of all the projects is 2 days (2.38\% of total duration of the project) and the maximum time overrun is 335 days $(66.47 \%$ of total duration of the project). The average time overrun for the construction projects are $34.74 \%$. In term of number of project, 17 of 30 of projects (56.67\%) were facing 1-100 days time overrun, 5 (16.67\%) projects in between 101 to 200 days, 5 (16.67\%) projects 201 to 300 days whereas $3(10 \%)$ projects were delayed for time period above 300 days. The summary of time overrun of the projects in terms of duration is summarized in Figure 1.

Table 2: List of Projects facing time over run

\begin{tabular}{|l|l|c|c|c|c|}
\hline No. & \multicolumn{1}{|c|}{ Name of Project } & $\begin{array}{c}\text { Project } \\
\text { Cost } \\
\text { (Million } \\
\text { RM) }\end{array}$ & $\begin{array}{c}\text { Project } \\
\text { Duration } \\
\text { (days) }\end{array}$ & $\begin{array}{c}\text { Time } \\
\text { Overrun } \\
\text { (Days) }\end{array}$ & $\begin{array}{c}\text { \% Time } \\
\text { Overrun }\end{array}$ \\
\hline & State of PERAK & & & & \\
\hline 1 & Construction of MRSM Kroh, & 33.6 & 504 & 335 & 66.47 \\
\hline 2 & Construction of MRSM Kuala Kangsar, Perak & 40.3 & 545 & 4 & 0.73 \\
\hline 3 & Enlarge/Upgrade of IKM Lumut, Perak. & 11.2 & 700 & 35 & 5.00 \\
\hline 4 & Construction of KKTM Lenggong, Perak. & 113.3 & 791 & 21 & 2.65 \\
\hline 5 & Fixing of Slipway Winh System, MIMET & 1.3 & 265 & 68 & 25.66 \\
\hline & State of SELANGOR & & & & \\
\hline
\end{tabular}




\begin{tabular}{|c|c|c|c|c|c|}
\hline 6 & $\begin{array}{l}\text { Construction of MRSM, Tanjung Karang, } \\
\text { Selangor }\end{array}$ & 47.9 & 503 & 326 & 64.81 \\
\hline 7 & Construction of New GMI Campus & 333.2 & 910 & 7 & 0.77 \\
\hline 8 & Enlargement of MFI Campus, Bangi & 13.0 & 545 & 194 & 35.60 \\
\hline 9 & Construction of MSI welding workshop, Kulim & 1.8 & 168 & 76 & 45.24 \\
\hline \multirow[t]{2}{*}{10} & Construction of FDRC at Fitec & 1.6 & 84 & 2 & 2.38 \\
\hline & State of PAHANG & & & & \\
\hline 11 & Construction of MRSM, Pekan. Pahang & 48.5 & 671 & 153 & 22.80 \\
\hline 12 & Construction of MRSM, Bentong. Pahang. & 55.0 & 504 & 76 & 15.08 \\
\hline 13 & Upgrading of MRSM, Kuala Lipis. & 3.6 & 349 & 4 & 1.15 \\
\hline \multirow[t]{2}{*}{14} & Construction of KKTM Kuantan, Pahang & 66.4 & 728 & 256 & 35.16 \\
\hline & State of TERENGGANU & & & & \\
\hline 15 & Upgrade of MRSM Kuala Terengganu & 2.8 & 279 & 332 & 119.00 \\
\hline 16 & Construction of IKM Kemaman, Terengganu & 67.0 & 713 & 18 & 2.52 \\
\hline \multirow[t]{2}{*}{17} & $\begin{array}{l}\text { Construction of } 1 \text { Unit PMN Banglo, } \\
\text { Terengganu }\end{array}$ & 0.3 & 219 & 84 & 38.36 \\
\hline & State of SARAWAK & & & & \\
\hline 18 & Construction of MRSM Betong, Sarawak. & 42.6 & 728 & 34 & 4.67 \\
\hline \multirow[t]{2}{*}{19} & Construction of MRSM Mukah, Sarawak & 48.0 & 727 & 203 & 27.92 \\
\hline & State of NEGERI SEMBILAN & & & & \\
\hline \multirow[t]{2}{*}{20} & $\begin{array}{l}\text { Upgrade of MRSM Kuala Klawang, Negeri } \\
\text { Sembilan. }\end{array}$ & 13.0 & 909 & 66 & 7.26 \\
\hline & State of KELANTAN & & & & \\
\hline \multirow[t]{2}{*}{21} & Construction of MRSM Tumpat, Kelantan & 48.7 & 538 & 127 & 23.61 \\
\hline & State of PERLIS & & & & \\
\hline \multirow[t]{2}{*}{22} & Construction of MRSM Arau, Perlis & 38.6 & 727 & 241 & 33.15 \\
\hline & State of SABAH & & & & \\
\hline \multirow[t]{2}{*}{23} & Construction of MRSM Sandakan, Sabah & 87.5 & 700 & 31 & 4.43 \\
\hline & State of MELAKA & & & & \\
\hline 24 & Enlargement/Upgrade of IKM Jasin, Melaka. & 47.0 & 364 & 138 & 37.91 \\
\hline \multirow[t]{2}{*}{25} & $\begin{array}{l}\text { Construction of Kolej Profesional MARA } \\
\text { Tiang Dua, }\end{array}$ & 29.8 & 504 & 213 & 42.26 \\
\hline & State of JOHOR & & & & \\
\hline 26 & Construction of IKM Sri Gading, Johor. & 72.9 & 511 & 273 & 53.42 \\
\hline 27 & Enlargement of IKM Johor Bharu, Johor. & 9.4 & 413 & 263 & 63.68 \\
\hline
\end{tabular}




\begin{tabular}{|l|l|c|c|c|c|}
\hline 28 & Construction of IKM Muar, Johor. & 64.3 & 728 & 55 & 7.55 \\
\hline 29 & $\begin{array}{l}\text { Construction of ILHAM (Institut Latihan dan } \\
\text { Kecemerlangan) MARA }\end{array}$ & 33.1 & 279 & 76 & 27.24 \\
\hline 30 & $\begin{array}{l}\text { Construction of INTEM (Kompleks Inkubator } \\
\text { Teknologi Makanan Kepong) }\end{array}$ & 9.4 & 349 & 77 & 22.06 \\
\hline \multicolumn{3}{|r|}{$\begin{array}{r}\text { Minimum Time Overrun } \\
\text { Maximum Time Overrun } \\
\text { Average Time Overrun }\end{array}$} & $\begin{array}{l}335 \text { days } \\
23.74 \%\end{array}$ \\
\hline
\end{tabular}

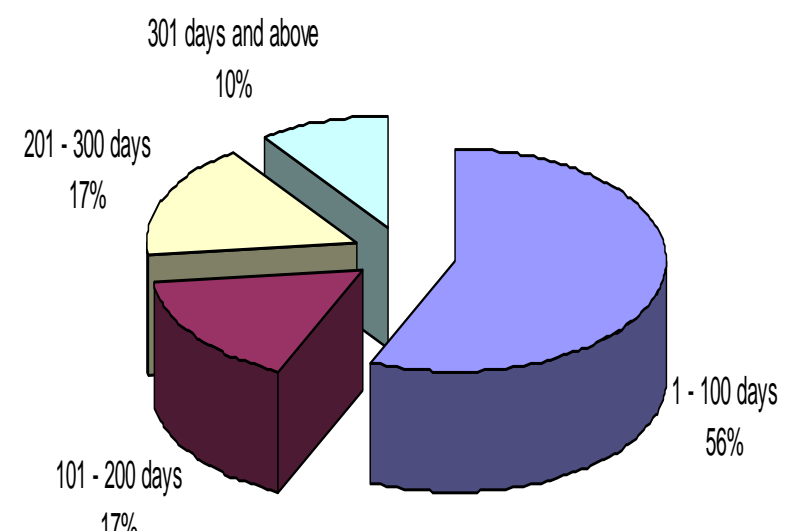

Figure 1. :\% projects facing time overrun in term of days

\section{Pilot Survey of Identifying Factors Affecting Time Overrun}

Initially, significant factors of time overrun were retrieved from literature review and mapped based on the frequency occurrences. This resulted to 30 factors attributed from studies conducted around the world (Ogunlana et al. (1996), Chan and Kumaraswamy (1997), Al-Khalil and Al-Ghafly (1999), Odeh and Battaineh (2002), Frimpong et al. (2003) Long et al (2004), Assaf and Al-Hejji (2006), Sweis et al (2007, Le-Hoai et al. (2008), El-Razek et al. (2008) and Fong et al., 2006).

The 30 factors were listed and a pilot questionnaire survey and interviews were conducted among three groups of expert respondents i.e. clients (6 responds), project management consultant ( 9 responds) and contractor (6 responds) senior personnel. The expert respondents were requested to rank from 1 to 30 according to their opinions in the ranking form where the smaller numbers represent "higher significance" while the higher numbers represent 'less significance'. The response from the respondents shows the initial trend of the respondents towards the causes of construction time overrun.

Data gathered was analyzed by calculating the average of the score by using the formula:

$X=\frac{1}{n} \sum_{i=1}^{n} a_{i}$ 
Where,

$$
\begin{aligned}
& X=\text { arithmetic mean, } \\
& n=\text { number of respondents; and } \\
& a=\text { score of respondents }(i=1 \ldots . . n)
\end{aligned}
$$

The results of pilot study are tabulated as in Table 3. The feedbacks from each of the respondents were ranked. Only the top 10 factors from each group were selected and sorted to avoid duplication. This resulted to 18 significant factors as shown in Table 4. In the second phase, a structured questionnaire survey

\begin{tabular}{|c|c|c|c|c|c|c|c|}
\hline \multirow{2}{*}{$\begin{array}{l}\text { S. } \\
\text { No }\end{array}$} & \multirow{2}{*}{$\begin{array}{l}\text { Causes of time overrun/ } \\
\text { Respondents }\end{array}$} & \multicolumn{2}{|c|}{$\begin{array}{c}\text { PMC } \\
\text { Respondents }\end{array}$} & \multicolumn{2}{|c|}{$\begin{array}{c}\text { Client } \\
\text { Respondents }\end{array}$} & \multicolumn{2}{|c|}{$\begin{array}{l}\text { Contractor } \\
\text { Respondents }\end{array}$} \\
\hline & & $\underset{⿱ ⺌}{\longleftarrow}$ & 光 & $\underset{⿱ ⺌}{\longleftarrow}$ & 压 & $\sum_{4}^{\infty}$ & 气ี \\
\hline 1 & $\begin{array}{l}\text { Practice of assigning contract to } \\
\text { lowest bidder }\end{array}$ & 6.22 & 1 & 11.83 & 9 & 6.33 & 3 \\
\hline 2 & Contractor's poor site management & 8.00 & 2 & 5.17 & 1 & 17.50 & 25 \\
\hline 3 & $\begin{array}{l}\text { Cash flow and financial difficulties } \\
\text { faced by contractors }\end{array}$ & 9.00 & 3 & 7.17 & 4 & 7.33 & 5 \\
\hline 4 & $\begin{array}{l}\text { Ineffective planning and scheduling } \\
\text { by contractors }\end{array}$ & 9.89 & 4 & 5.67 & 3 & 15.33 & 20 \\
\hline 5 & Problems with subcontractors & 11.11 & 5 & 8.33 & 8 & 12.00 & 13 \\
\hline 6 & Inadequate contractor experience & 11.33 & 6 & 7.50 & 5 & 14.17 & 18 \\
\hline 7 & Material procurement & 11.89 & 7 & 13.50 & 16 & 16.00 & 22 \\
\hline 8 & Underestimate project duration & 12.33 & 8 & 8.00 & 7 & 10.33 & 11 \\
\hline 9 & $\begin{array}{l}\text { Incompetent designers } \\
\text { contractors }\end{array}$ & 12.44 & 9 & 12.00 & 10 & 14.83 & 19 \\
\hline 10 & Shortage of site workers & 12.56 & 10 & 13.83 & 17 & 10.33 & 10 \\
\hline 11 & Shortages of construction materials & 13.11 & 11 & 19.68 & 28 & 13.00 & 17 \\
\hline 12 & Change management & 13.44 & 12 & 5.33 & 2 & 17.67 & 26 \\
\hline 13 & Escalation of material prices & 13.67 & 13 & 14.83 & 22 & 9.17 & 8 \\
\hline 14 & $\begin{array}{l}\text { Mistakes during the construction } \\
\text { stage }\end{array}$ & 13.67 & 14 & 17.67 & 27 & 12.17 & 14 \\
\hline 15 & Labour productivity & 13.89 & 15 & 16.17 & 24 & 11.17 & 12 \\
\hline 16 & $\begin{array}{l}\text { Lack of communication between } \\
\text { parties }\end{array}$ & 14.56 & 16 & 13.00 & 13 & 5.50 & 1 \\
\hline 17 & Low speed of decision making & 14.67 & 17 & 14.33 & 19 & 7.33 & 6 \\
\hline 18 & Changes in scope of projects & 15.11 & 18 & 12.83 & 12 & 6.83 & 4 \\
\hline 19 & Poor technical performances & 16.78 & 19 & 14.00 & 18 & 12.67 & 15 \\
\hline 20 & Improper techniques and tools & 16.89 & 20 & 17.33 & 26 & 12.83 & 16 \\
\hline 21 & Improper site co-ordination and & 18.67 & 21 & 12.17 & 11 & 20.00 & 27 \\
\hline
\end{tabular}
was conducted among the Project Management Consultant (PMC) personnel in the company organization.

Table 3: Preliminary Ranking Cause of Time overruns 


\begin{tabular}{|c|l|c|c|c|c|c|c|}
\hline & $\begin{array}{l}\text { management of the electrical and } \\
\text { mechanical installation. }\end{array}$ & & & & & & \\
\hline 22 & Frequent changes by owners & 19.11 & 22 & 16.83 & 25 & 7.67 & 7 \\
\hline 23 & Difficulties in getting work permit & 20.56 & 23 & 13.50 & 15 & 15.67 & 21 \\
\hline 24 & Unforeseen ground condition & 20.89 & 24 & 7.67 & 6 & 5.67 & 2 \\
\hline 25 & $\begin{array}{l}\text { Inadequate client's finance and } \\
\text { payments for completed work }\end{array}$ & 21.56 & 25 & 21.17 & 30 & 20.67 & 29 \\
\hline 26 & Owner interference & 21.89 & 26 & 14.83 & 21 & 10.00 & 9 \\
\hline 27 & $\begin{array}{l}\text { defects identified during the fire } \\
\text { services inspection }\end{array}$ & 22.11 & 27 & 19.83 & 29 & 22.00 & 30 \\
\hline 28 & Necessary variations of works & 22.22 & 28 & 15.33 & 23 & 16.67 & 24 \\
\hline 29 & Equipment availability and failure & 22.22 & 29 & 13.33 & 14 & 20.33 & 28 \\
\hline 30 & Social and technological issues & 24.00 & 30 & 14.67 & 20 & 16.33 & 23 \\
\hline
\end{tabular}

Table 4: Top-10 Analysis Responses by All Selected Respondents

\begin{tabular}{|l|l|}
\hline S.No. & \multicolumn{1}{|c|}{ Cause of Time Overrun } \\
\hline 1 & Practice of assigning contract to lowest bidder \\
\hline 2 & Contractor's poor site management \\
\hline 3 & Cash flow and financial difficulties faced by contractors \\
\hline 4 & Ineffective planning and scheduling by contractors \\
\hline 5 & Problems with subcontractors \\
\hline 6 & Inadequate contractor experience \\
\hline 7 & Material procurement \\
\hline 8 & Poor estimate project duration \\
\hline 9 & Incompetent designers \\
\hline 10 & Shortage of site workers \\
\hline 11 & Lack of communication among parties \\
\hline 12 & Unforeseen ground condition \\
\hline 13 & Changes in scope of projects \\
\hline 14 & Low speed of decision making \\
\hline 15 & Frequent changes by owners \\
\hline 16 & Escalation of material prices \\
\hline 17 & Owner interference \\
\hline 18 & Change management \\
\hline
\end{tabular}




\subsection{Results and discussion}

Structured questionnaire survey based on 18 factors retrieved from table 4 was conducted among the personnel of Project Management Consultants (PMC). A total of 45 questionnaire sets were distributed and 37 responses were received which formed $82.22 \%$ of responses. Results of collected are discussed below:

\subsection{Respondent Demographics}

The respondent involved in survey had several years of experience in handling big/large projects. The demographic results of the respondents participated in survey are summarized in Table 5. The results show that only 7 of 30 respondents (18.9\%) had working experiences of 6 to 10 years. However, majority of respondents i.e. 30 of $37(81.1 \%)$ respondents had working experiences above 10 years. This implies that respondents have adequate experience to give reliable information pertaining time overrun factors.

As indicated in the table, majority (73\%) of the respondents had obtained degree in civil engineering, $5.4 \%$ with mechanical engineering, $8.1 \%$ in electrical engineering and $13.5 \%$ others related discipline. This related discipline includes Quantity Surveyor, Architect and diploma certifications. In term of the project size handled by respondents, the results show that all of the respondents experienced in handling large construction projects i.e. the contract amount of project exceed RM 5 million (Abdullah et al. 2009).

Table 5: Respondents Demographic

\begin{tabular}{|l|c|c|c|}
\hline & Frequency & Percent & Cumulative Percent \\
\hline Experiences & 7 & 18.9 & 18.9 \\
6-10 Years & 30 & 81.1 & 100 \\
Above 10 Years & & & \\
& & 73.0 & 73.0 \\
Respondent Specialization & 27 & 5.4 & 78.4 \\
Civil Engineering & 2 & 8.1 & 86.5 \\
Mechanical Engineering & 3 & 13.5 & 100 \\
Electrical Engineering & 5 & & \\
Other & & 13.5 & 13.5 \\
Size of Project & 5 & 86.5 & 100 \\
10-50 Million & 32 & & \\
Above 50 Million & & & \\
\end{tabular}

\subsection{Ranking of Factors Affecting Time Overrun}

The respondents were requested to mark a five point likert-scale of 1 to 5 . The scale was adopted to assess the degree of agreement of each cause where 1 represented 'strongly disagree', 2 'disagree', 3 'moderately agree', 4 'agree' and 5 'strongly agree'. Statistical Package for Social Science (SPSS) version 17 was used to analyze the data. The data collected was tested for level of agreement with Kendall's test. Results are presented in Table 6. Kendall's coefficient of concordance W is used to test or measure the agreement among respondents. 
Table 6: Kendall's Coefficient of Concordance Results

\begin{tabular}{|l|l|}
\hline $\mathrm{N}$ & 37 \\
\hline Kendall's W & 0.364 \\
\hline Chi-Square & 228.932 \\
\hline Df & 17 \\
\hline Asymp. Sig. & 0 \\
\hline
\end{tabular}

Based on the result of test statistics as in Table 6, Kendall's W for the whole data is 0.364 (W >0), which conclude that there are moderate level of agreement among respondents. Data was tested for reliability to check the consistency of the data. The Cronbach $\alpha$ coefficient was used to measure the inner consistency. From the analysis, the Cronbach $\alpha$ of the data was 0.603 . This reflected that the collected data was valid and reliable since the value of alpha is desirable with the range higher than 0.6 (Meepol \& Ogunlana, 2006). Once the validity and reliability had been decided, the data was then analyzed to calculate ranking of time over run causes is calculated based on the mean rank score. The higher the mean rank score shows the higher is the ranking. The formula used for the mean rank calculation is;

$M_{R}=\frac{\bar{R}}{M_{\max }} n$

Where $\mathrm{M}_{\mathrm{R}}$ is Mean Rank, $\bar{R}$ is Individual Mean Rank of cause, $\mathrm{R}_{\max }$ is the Maximum Individual Mean Rank of cause and $\mathrm{n}$ is the number of causes. The determination of 'significance' of causes is based on the mean rank scored. In this study, the mean rank score of 12.6 (individual mean 3.5) is used as cut-off point for significant cause of time overrun and the mean rank score of 9 to 12.6 (individual mean 2.5-3.5) which is translated into 'moderately agree' rating in the likert scale is considered as moderate significant cause of time overrun. The results of ranks analysis are as compiled in Table 7.

Table 7: Ranking Cause of Time overrun by PMC

\begin{tabular}{|l|c|c|}
\hline Cause of Time overrun & Mean Rank & Rank \\
\hline Cash flow and financial difficulties faced by contractors & 13.8 & 2 \\
\hline Contractor's poor site management & 12.74 & 3 \\
\hline Inadequate contractor experience & 12.61 & 4 \\
\hline Shortage of site workers & 12.36 & 5 \\
\hline Ineffective planning and scheduling by contractors & 12.18 & 6 \\
\hline Escalation of material prices & 11.27 & 7 \\
\hline Practice of assigning contract to lowest bidder & 11.01 & 8 \\
\hline Problems with subcontractors & 10.47 & 2 \\
\hline
\end{tabular}




\begin{tabular}{|l|c|c|}
\hline Lack of communication among parties & 10.32 & 9 \\
\hline Change management & 9.69 & 10 \\
\hline Late in material procurement & 9.66 & 12 \\
\hline Incompetent designers & 9.46 & 13 \\
\hline Poor estimate project duration & 8.07 & 14 \\
\hline Low speed of decision making & 6.11 & 15 \\
\hline Unforeseen ground condition & 6.00 & 16 \\
\hline Changes in scope of projects during construction work & 5.93 & 17 \\
\hline Frequent design changes & 5.00 & 18 \\
\hline Owner interference in construction work/process & 4.31 & \\
\hline
\end{tabular}

Table 7 indicates that respondents ranked "Cash flow and financial difficulties faced by contractors" in the first position with mean rank of 13.8. PMC believes this issue is very critical where it may influence other causes such as contractor's poor site management, shortage of site workers and ineffective planning and scheduling. Settling this issue may as well settle other issues simultaneously. Various studies have shown that in view of consultants' cash flow and financial difficulties of contractor play vital role in the time performance and delay of project. El-Razek et al. (2008) study found that the consultants rank this factor as the most significant factor affecting construction time in Egypt. However, in Le-Hoai (2008) study on Vietnamese construction found that this factor was ranked as $4^{\text {th }}$ important factor affecting project time. Similarly, Frimpong et al. (2003) study in Ghana mentioned that contractor's financial difficulties were ranked as $3^{\text {rd }}$ and cash flow during construction were ranked that $5^{\text {th }}$ important factor affecting construction time. While in Saudi Arabia and Hong Kong this factor was ranked as $7^{\text {th }}$ and $13^{\text {th }}$ respectively (Assaf \& Al-Hejji,2006 and Fong et al., 2006).

Contractor's poor site management was ranked second highest for causing time overrun. Contractor's poor site management such as late to comply with statutory bodies requirement, poor communication with subcontractors and material suppliers are significantly affect the progress of the project. To make matter worst, the frequent change of site manager/supervisor distracted the continuity of the site management. Unfortunately, LeHoai (2008) and Fong et al., (2006) studies found that the consultants ranked this factor as most significant factor contributing to time overrun. While in Saudi Arabia, the consultants ranked this factor as $8^{\text {th }}$ important factor as reported by Assaf \& Al-Hejji (2006)

The third highest rank cause of time overrun as perceived by PMC is inadequate contractor experience. PMC believes that lack of contractor experience in the same capacity/scope of job has resulted in difficulties in handling the project efficiently. Experience contractors will be able to achieve high standards of quality and workmanship, high percentage of success projects and have good safety records. The real issue here is the lack of experience of management team at the site. The contractor seems to hire young and inexperienced personnel to work there.

Shortage of site workers is also quite significant as perceived by PMC. It is 4th ranked cause of time overrun. The PMC claims that problems between contractor and sub-contractor seems largely contribute to this cause. As most of works are contracted to sub contractors, most of the workers are hired by these sub-contractor. 
If there are disputes between contractor and sub-contractor, automatically this issue prevails. Assaf \& Al-Hejji (2006) and Fong et al. (2006) reported that shortage of labour is one of the important factors affecting construction time in Saudi Arabia and Hong Kong with and were ranked as $2^{\text {nd }}$ and 4 rth respectively.

Effective planning and scheduling plays a very important role in success of any project. Survey results show that PMC ranked ineffective planning and scheduling by contractors as quite significant cause of time overrun. This issue seems to be true as it is highly related to cash flow and financial difficulties faced by contractors, shortage of site workers, contractor's poor site management, inadequate contractor experience, lack of communication among construction parties, problems with subcontractors, and frequent change management. In Ghana, consultants report this that ineffective planning and scheduling is $2^{\text {nd }}$ most critical factor affecting construction time (Frimpong et al., 2003), while Assaf \& Al-Hejji (2006) found that consultants of Saudi Arabia reported this factor as $4^{\text {th }}$ important factor.

The five most important causes of cost overruns of Malaysian construction industry compared to different countries from consultant's perspectives are presented in Table 8. This study contributes to the trend of cost over run causes faced by different countries.

Table 8: Comparison of Causes of Time Overrun among Various Countries

\begin{tabular}{|c|c|c|c|c|c|}
\hline & \multicolumn{5}{|c|}{ Major Causes } \\
\hline & Rank 1 & Rank 2 & Rank 3 & Rank 4 & Rank 5 \\
\hline $\begin{array}{l}\text { This } \\
\text { Study } \\
(2011)- \\
\text { Malaysia }\end{array}$ & $\begin{array}{l}\text { Cash flow } \\
\text { and financial } \\
\text { difficulties } \\
\text { faced by } \\
\text { contractors }\end{array}$ & $\begin{array}{l}\text { Contractor's } \\
\text { poor site } \\
\text { management }\end{array}$ & $\begin{array}{l}\text { Inadequate } \\
\text { contractor } \\
\text { experience }\end{array}$ & $\begin{array}{l}\text { Shortage of } \\
\text { site workers }\end{array}$ & $\begin{array}{l}\text { Ineffective } \\
\text { planning and } \\
\text { scheduling by } \\
\text { contractors }\end{array}$ \\
\hline $\begin{array}{l}\text { Le-Hoai } \\
(2008)- \\
\text { Vietnam }\end{array}$ & $\begin{array}{l}\text { Poor site } \\
\text { management } \\
\text { and } \\
\text { supervision }\end{array}$ & $\begin{array}{l}\text { Poor project } \\
\text { management } \\
\text { assistance }\end{array}$ & $\begin{array}{l}\text { Financial } \\
\text { difficulties of } \\
\text { owner }\end{array}$ & $\begin{array}{l}\text { Financial } \\
\text { difficulties of } \\
\text { contractor }\end{array}$ & Design changes \\
\hline $\begin{array}{l}\text { El-Razek } \\
\text { et al. } \\
\text { (2008) - } \\
\text { Egypt }\end{array}$ & $\begin{array}{l}\text { Financing by } \\
\text { contractor } \\
\text { during } \\
\text { construction }\end{array}$ & $\begin{array}{l}\text { Non-utilization } \\
\text { of professional } \\
\text { construction/ } \\
\text { contractual } \\
\text { management }\end{array}$ & $\begin{array}{l}\text { Delays in } \\
\text { contractor's } \\
\text { payment by } \\
\text { owner }\end{array}$ & $\begin{array}{l}\text { Preparation of } \\
\text { shop drawings } \\
\text { and material } \\
\text { samples }\end{array}$ & $\begin{array}{l}\text { Difficulty of } \\
\text { coordination } \\
\text { between various } \\
\text { Parties }\end{array}$ \\
\hline $\begin{array}{l}\text { Assaf and } \\
\text { Al-Hejji } \\
(2006)- \\
\text { Saudi } \\
\text { Arabia }\end{array}$ & $\begin{array}{l}\text { Type of } \\
\text { project } \\
\text { bidding and } \\
\text { award }\end{array}$ & $\begin{array}{l}\text { Shortage of } \\
\text { labours }\end{array}$ & $\begin{array}{l}\text { Delay in } \\
\text { progress } \\
\text { payments by } \\
\text { owner }\end{array}$ & $\begin{array}{l}\text { Ineffective } \\
\text { planning and } \\
\text { scheduling of } \\
\text { project by } \\
\text { contractor }\end{array}$ & $\begin{array}{l}\text { Change orders } \\
\text { by owner during } \\
\text { construction }\end{array}$ \\
\hline $\begin{array}{l}\text { Fong et al. } \\
\text { (2006) - } \\
\text { Hong } \\
\text { Kong }\end{array}$ & $\begin{array}{l}\text { Poor site } \\
\text { management } \\
\text { and } \\
\text { Supervision }\end{array}$ & $\begin{array}{l}\text { Qualification } \\
\text { and } \\
\text { experience of } \\
\text { project staff }\end{array}$ & $\begin{array}{l}\text { Insufficient } \\
\text { project staff }\end{array}$ & $\begin{array}{l}\text { Insufficient } \\
\text { labour }\end{array}$ & $\begin{array}{l}\text { Improper E\&M } \\
\text { coordination } \\
\text { and } \\
\text { management }\end{array}$ \\
\hline $\begin{array}{l}\text { Frimpong } \\
\text { et al. } \\
\text { (2003) - } \\
\text { Ghana }\end{array}$ & $\begin{array}{l}\text { Monthly } \\
\text { payment } \\
\text { difficulties }\end{array}$ & $\begin{array}{l}\text { Poor contract } \\
\text { management }\end{array}$ & $\begin{array}{l}\text { Contractor's } \\
\text { financial } \\
\text { difficulties }\end{array}$ & $\begin{array}{l}\text { Planning and } \\
\text { scheduling } \\
\text { deficiencies }\end{array}$ & $\begin{array}{l}\text { Cash flow } \\
\text { during } \\
\text { construction }\end{array}$ \\
\hline
\end{tabular}




\section{Conclusion}

It can be concluded that the results from this study are moderately similar to the findings of other studies. PMC believes that contractors are responsible for time overrun issues in construction project. In order to achieve project completion on time, contractors are required to manage their cash flow and utilize their financial resource more effectively. Also, effective planning \& scheduling is essentially required and project schedule need to be updated regularly and skilled staff be hired so that project can be managed properly and effectively. Based on the findings of the study, authors recommend that contractors are required,

- To have an adequate cash flow plan,

- Manage Financial resources

- Improve site management by hiring skilled staff

- Proper planning and scheduling being carried out,

- Schedule be updated regularly

The results of this study can help to understand the dynamic factors that caused the time overrun and thus, an opportunity to develop some system to reduce the causes of time over run.

\section{References}

Abdul Rashid, K. 2002. Construction Procurement in Malaysia, International Islamic University Malaysia.

Abdullah M.R, Abdul Azis A.A and Abdul Rahman I. 2009. Causes of delay and its effects in large MARA construction project. International journal of Integrated Engineering (Issue on Mechanical, Materials and Manufacturing Engineering)

Al-Khalil, M. I and Al-Ghafly, M. A. 1999. Delays in public utility projects in Saudi Arabia, International Journal of Project Management, Vol. 17(2): pp. 101-106

Assaf, S.; and Al-Hejji, S. 2006. Causes of delay in large construction projects in Saudi Arabia, International Journal of project management 24 (4): 349-57.

Chan, D. W. M.; and Kumaraswamy, M. M. 1997. A comparative study of causes of time overruns in Hong Kong construction projects, International Journal of Project management 15(1): 55-63.

CIDB 2007. Construction Industry Master Plan (CIMP) 2006-2015.

El-Razek; M. E. A; Bassioni, H..A and Mobarak, A. M (2008). Causes $\mathrm{f}$ delay in Building Construction Projects in Egypt, Journal of Construction Engineering and Management, Vol. 134 (11): pp. 831-841

Fong, N.K.; Wong, L.Y and Wong, L.T (2006). Fire services installation related contributors of construction delays, Building and Environment, volume 41, pages: 211-222

Frimpong, Y.; Oluwoy, J.; Crawford, L. 2003. Causes of delay and cost overruns in construction of groundwater projects in a developing countries: Ghana as a case study, International Journal of Project management 21.

Kaliba, C.; Muya, M.; Mumba, K. 2009. Cost escalation and schedule delays in road construction projects in Zambia, International Journal of Project Management 27: 522-531. 
Kaming, P.; Olomolaiye, P.; Holt, G.; Harris, F. 1997. Factors influencing construction time and cost overruns on high-rise projects in Indonesia, Construction Management and Economics (15): 83-94.

Le-Hoai, L; Lee, Y. D and Lee J. Y (2008) "Delay and Cost Overruns in Vietnam Large Construction Projects: A Comparison with Other Selected Countries”, KSCE Journal of Civil Engineering 12(6):367-377

Long, N.D., Ogunlana, S., Quang, T., and Lam, K.C. 2004. Large construction projects in developing countries: a case study Vietnam.” International Journal of Project Management, Volume 22, Pages: 553-561.

Mansfield, N. R.; Ugwu, O. O.; Doran, T. 1994. Causes of delay and cost overruns in Nigerian construction projects, International Journal of Project Management 12: 254-260.

Meepol S and Ogunlana S. O. 2006. Factors affecting cost and time performance on highway construction projects: evidence from Thailand. Journal of Financial Management of Property and Construction; 11(1): $3: 20$

Odeh, A. M and Battaineh, H. T. 2002. Causes of Construction delay: traditional Contracts, International Journal of Project Management 20: 67- 73

Ofori, G. 1990. The Construction Industry; aspects of its economics and management, Singapore University Press.

Ogunlana, S. O and Promkuntong, K. 1996. Construction delays in a fast-growing economy: Comparing Thailland with other economies" International Journal of Project Management 14 (1) 37-45

Rwelamilla. P. D.; and Hall, K. A 1995. Total systems intervention: an integrated approach to time, cost and quality management, Construction Management and Economics 13: 235-241.

Sweis, G.; Sweis, R.; Abu Hammad, A.; Shbpul, A. 2008. Delays in construction projects: The case of Jordan, International Journal of Project management 26 (6): 665-674

Yang, J. B; Ou, S. F. 2008. Using structural equation modeling to analyze relationships among key causes of delay in construction. Canadian Journal of Civil Engineeing 35: 321-332 